\title{
Impact of green supply chain practices on financial and non-financial performance of Vietnam's tourism enterprises
}

\author{
Thi Thu Hoai Nguyen ${ }^{a}$, Thi Lua Pham ${ }^{b}$, Thi Thu Hien Phan ${ }^{b^{*}}$, Trong Thuy Than ${ }^{c}$ and Thi \\ Quynh Anh Nguyena
}

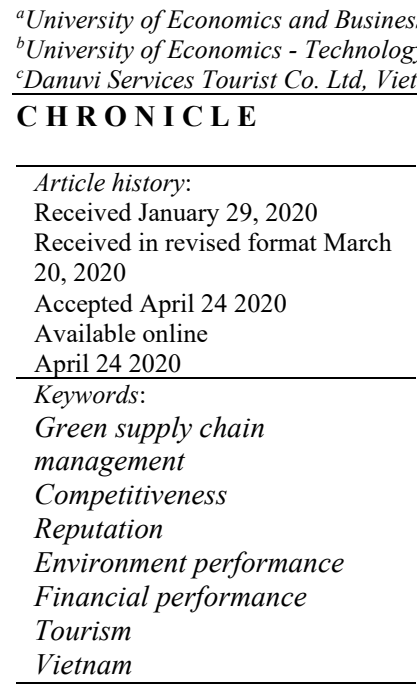

\section{Introduction}

Vietnam's renaissance continues to move in all areas and plays an important role in economic growth, social security, cultural preservation and environmental protection. However, tourism growth poses challenges for sustainable development and determines the environmental and social responsibilities of the parties. The tourism industry, as an inevitable trend, must move towards green tourism, because the tourism industry depends on natural resources and must also protect nature for development. Therefore, the industry must have a negative impact on the environment, climate change depending on natural conditions, a tourist destination with high seasonal characteristics such as beaches, can destroy tourist destinations. Overall, tourism can cause environmental pollution or devastate other economic activities in many areas. The most directly observable fact is that the movement of long lines of tourists around the world accompanied by an increase in waste, emissions, and traffic congestion make the quality of life of the local people reduction method. Along with the development of transportation and

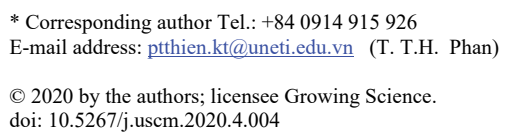


communication, more and more tourists are exploring more remote areas of the earth, indirectly creating an ecological imbalance. For example, the innocent exploitation of coral reefs along with the Pacific Ocean expedition to serve the needs of tourists has partly caused atmospheric fluctuations that caused El Nino - Southern Oscillation, the green tourism supply chain associated with sustainable development has become the object of research and development of a theoretical framework with the desire to minimize the negative impact of the tourism supply chain on the environment.

In order to build a green tourism environment, the management of the supply chain in the tourism industry is very important. Because, in order to develop comprehensively and sustainably, all issues must be solved in a synchronous manner from supply to final product consumption. The topics on the impact of green supply chain management on financial efficiency and non-financial efficiency such as environmental management efficiency, increasing competitive advantage and improving the image of enterprises have been studied in reality. In different contexts, or only in a small area of the tourism industry such as restaurants (Chiu \& Hsieh, 2016; Bagur-Femenias et al. 2013). In the context of the tourism industry, there are still very few research authors on this topic, this is a specific service industry and there are many differences compared to other manufacturing industries. Especially in the context of a country with a developing economy like Vietnam, almost no research has been conducted. Therefore, we conduct this study with the desire to contribute to the theoretical basis of this topic in the context of Vietnam's tourism industry.

The structure of the article in addition to the introduction includes: Research overview, research methods, research results and conclusions.

\section{Literature review}

\subsection{Green tourism}

The concept of green tourism has been mentioned a lot since the 1980s but was not widely adopted until the concept of ecotourism. Many scholars have come up with their own views on green tourism that emphasize different meanings in terms of scale, respect for nature, and minimize environmental impact. According to Pintassilgo (2016), Chan and Wong (2006), green tourism is an alternative form of tourism often associated with rural tourism, which is a form of nature tourism, environmentally friendly and hardly impacting the ecology at a travel destination. Thus, in this sense, green tourism has been used instead of concepts such as ecotourism, nature tourism, and rural tourism (Pintassilgo, 2016). Many businesses have embraced the idea of green tourism with a broader meaning: any tourism activity in an environmentally friendly manner is considered to be green tourism (Pintassilgo, 2016). According to Dodds and Joppe (2001) the concept of green tourism can be divided into the following four components: a) Environmental responsibility - protecting, preserving and enhancing the role of nature and the environment rational to ensure the long-term sustainability of the ecosystem; b) The long-term development capacity of the local economy - supporting local economies, businesses and communities to ensure economic development and sustainability; c) Biodiversity - appreciate cultures and cultural expressions to ensure that local cultures continue to thrive; d) Diversity of experiences - delivering rich and satisfying experiences through active, personal and meaningful participation, and engagement with nature, people, places and cultures. Many ecotourism businesses have successfully integrated environmental-friendly activities, sustainable development into operations and created tourist

experiences and increased profitability through sustainable business models. Specifically, environmentally responsible businesses have created new workplaces such as the Environmental Program Coordinator and Sustainable Management to achieve environmental goals. In many countries around the world, including Vietnam, the tourism industry is interested in restructuring towards sustainable development based on the value chain and quality of tourism services. Accordingly, creating new and diversified partnerships in business development. A growing green tourism industry needs to improve the efficiency of energy, water and waste systems. In fact, effective investment in the creation of energy sources, clean water and waste treatment will reduce operating costs, generate more profits, in a shorter payback period, and enhance the value of biodiversity, ecosystems and cultural 
heritage. Therefore, green tourism certainly requires quality, direct and indirect human resources, caring about the environment and implementing codes of conduct in line with the trend of being environmentally friendly. In addition, green tourism has the potential to create new jobs and benefit the environment. Green tourism development supports the local economy and poverty reduction through many employment opportunities and in the local tourism value and supply chain, as well as being important in promoting tourism in the direction of protecting tourism. survive and enrich the local culture and natural environment.

\subsection{Green supply chain management}

Green supply chain management is the implementation of business processes from the procurement of raw materials, to the production or supply of services and after-sales, distribution towards green environmentally friendly, business. responsibility. Green supply chain management practices involve organizations that evaluate the environmental management effectiveness of products purchased and sold as well as assessing the cost of treating waste and emissions of businesses (Paulraj, 2011; Zhu \& Sarkis, 2004). Green supply chain management activities include green design, purchasing, manufacturing / processing, manufacturing, service provision, marketing, recycling and sourcing. Implementing green supply chain management helps improve efficiency and increase synergies between partners, facilitating environmental protection, reducing waste and reducing negative impacts on the environment. save costs and improve operational efficiency (Rao \& Holt, 2005).

\subsection{Impact of GSCM on financial and non-financial performance}

Green supply chain management practices have positive impacts on environmental performance (Zhu et al., 2012). Experimental studies in different environments, different contexts show that the company's production process is significantly improved by reducing waste, reducing the consumption of toxic materials and thus deflation releasing toxic gases into the environment (Zhu \& Sarkis, 2004; Zhu et al., 2005). Practicing green supply chain management with suppliers and customers helps businesses work closely with each other, leading to opportunities to minimize negative environmental impacts. Other authors argue that selecting and working with suppliers take responsible actions on environmental issues that cause suppliers to act in a more environmentally friendly way and reduce their unsustainable behavior, therefore, creates a positive effect on the entire environmental performance of the focal company and the entire supply chain (Gimenez \& Sierra, 2013). Recent studies also suggest the positive impact of green supply chain management on financial performance (Zhu et al., 2012). According to Golicic and Smith (2013), green supply chain management will significantly improve the financial efficiency of businesses. The authors conducted an overview of more than 10 studies on green supply chain management practices and financial performance. The results show that green supply chain management has a positive and statistically significant impact on financial performance. It means that by focusing on green supply chain management both inside and outside the enterprise, businesses can reduce costs and improve operational efficiency (Gime'nez \& Sierra, 2013; Rao \& Holt 2005; Zhu \& Sarkis 2004; Zhu et al. 2012). By working closely with suppliers and customers to deliver the best transport solution, reducing $\mathrm{CO}_{2}$ emissions puts pressure on the environment which in turn leads to reduced production and consumption costs and better business results. In addition, by reducing the use of raw materials, eliminating hazardous product components, using raw materials and reducing the environmental impact of products through implementation of green supply chain management, They can create a competitive advantage and improve the reputation of the business thereby making a difference that improves the company's revenue and profit (Porter \& Kramer 2006).

\section{Research method}

\subsection{Research sample}

The sample is Hanoi tourism businesses, we send surveys to tourism businesses in Hanoi that are members of the Tourism Association through email and by post or in person. In a 6-week period we 
collect data with businesses that have been sent us by making phone calls or visiting in person. We have tried to gather all businesses that are members of Vietnam Tourism Association. As a result, we gathered about 150 questionnaires to analyze the data and test research hypotheses. We choose tourism businesses in Hanoi because Hanoi is the leading economic center of Vietnam. In addition, with limited time and resources, we chose Hanoi with the desire to represent the Vietnamese economy.

\subsection{Research models}

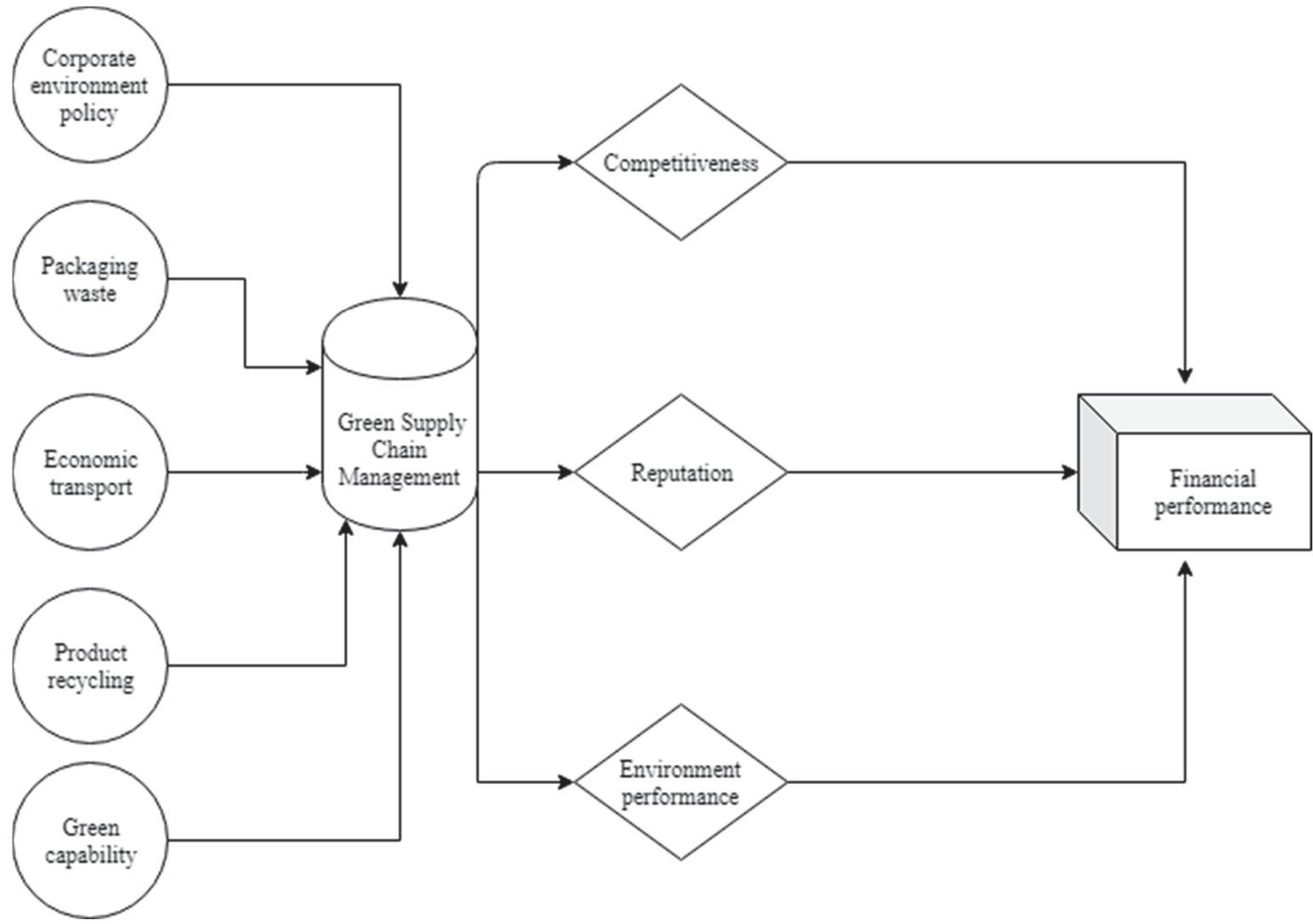

Fig. 1. Research model

Corporate environment policy: Tourism businesses in Vietnam, particularly in the Hanoi area, have carried out proper handling of wastes, furniture and products in green-friendly hotels. environmentally friendly. Building materials in travel businesses, managing energy-saving travel services. This variable is measured through 4 items developed from Chiu and Hsieh (2016). The scales are measured by a 5point Likert scale of 1 which is strongly disagree and 5 is strongly agree.

Packaging waste: The management of packaging waste is a very important issue in the tourism business in general, especially restaurants. Management of packaging waste not only has a strong impact on the cost and financial efficiency of the business but also affects the environment. Good control of packaging waste helps encourage innovation and continuous improvement of products and services and is a tool to reduce costs, improve reputation for businesses, hotels and help sustainable development. This latent variable is measured through 4 items using a 5-point Likert scale of 1 disagree completely and 5 strongly agree, the scales developed from Bagur-Femenias et al. (2013).

Economic transport: Transport means based on the principle of sustainable development, reducing $\mathrm{CO}_{2}$ emissions, using energy-efficient transport systems, increasing transportation efficiency, reducing the number and distance of transportation. This latent variable was measured through three items developed from Bagur-Femenias et al. (2013). The scales are measured by a 5-point Likert scale of 1 which is strongly disagree and 5 is strongly agree. 
Product recycling: Means businesses in the tourism industry in Hanoi, Vietnam such as hotels or event organizers or travel agencies to use recyclable products such as mugs packaging to reduce environmental impact and improve business reputation. This latent variable is measured by three items developed from Bagur-Femenias et al. (2013). The scales are measured by a 5-point Likert scale of 1 which is strongly disagree and 5 is strongly agree.

Green capability: This is associated with a greening strategy of tourism businesses in Hanoi and Vietnam. These are green activity, green supply chain management, green response, etc. This potential variable consists of 5 items is developed by Chiu and Hsieh (2016). The scales are measured by a 5point Likert scale of 1 which is strongly disagree and 5 is strongly agree.

Green supply chain management: A second order factor variable composed of five factors: Corporate environment policy; Packaging waste; Economic transport; Product recycling; Green capability.

Environmental performance: Environmental performance is the ability to reduce negative impacts on the environment such as reducing greenhouse gas emissions, reducing the discharge of untreated waste into the environment, limiting solid waste, using resources. Green materials, environmentally safe. Environmental performance is measured from 4 items developed from Chiu \& Hsieh (2016). The scales are measured by a 5-point Likert scale of 1 which is strongly disagree and 5 is strongly agree.

Reputation: The reputation of a business is measured through 5 items developed from research by Le et al. (2019). The scales are measured by a 5-point Likert scale of 1 which is strongly disagree and 5 is strongly agree.

Competitiveness: Competitiveness of a business is measured by 5 items developed from research by Phan et al (2019). The scales are measured by a 5-point Likert scale of 1 which is strongly disagree and 5 is strongly agree.

Financial performance: It is the ability to reduce the costs of purchasing raw materials, using energy, disposing of waste, discharging, improving the capacity and profitability of tourism businesses in Hanoi and Vietnam. Male. Includes 8 items developed from Zeng et al. (2010); Rodriguez (2012); Chiu and Hsieh (2016) and Phan et al. (2019). The scales are measured by a 5-point Likert scale of 1 which is strongly disagree and 5 is strongly agree.

Research hypotheses:

$\mathrm{H}_{1}$ : Green supply chain management has a positive impact on Competitiveness.

$\mathrm{H}_{2}$ : Green supply chain management has a positive impact on the Corporate reputation.

$\mathrm{H}_{3}$ : Green supply chain management has a positive effect on Environment performance.

$\mathrm{H}_{4}$ : Competitiveness has a positive impact on Financial performance.

$\mathrm{H}_{5}$ : Corporate Reputation has a positive effect on Financial performance.

$\mathrm{H}_{6}$ : Environment performance has a positive impact on Financial performance.

$\mathrm{H}_{7}$ : Green supply chain management has a positive direct impact on Financial performance.

H8: Competitiveness; Corporate reputation; Environment performance has a mediating role in the relationship between Green supply chain management and Financial performance.

\subsection{Analytical techniques}

Assessing reliability of scales: the commonly used reliability is the internal consistency of the scale reflecting the relationship of observed variables in the same scale. The reliability of the scale used in this study is Cronbach's coefficient Alpha. The collected data is entered into the computer via SPSS 20.0 statistical software. After coding and cleaning the data, it is acceptable since according to Hair et al. $(2011,2013,2014)$ using a Cronbach's Alpha coefficient with a Cronbach's Alpha coefficient of 0.6 or more is desirable. 
Discovery factor analysis (EFA): all observed variables relate to all factors by a factor load factor. The simple structure is achieved when each observed variable has a high load factor for only one factor and has a low load factor for other factors. Factor analysis is only used when KMO coefficient (KaiserMeyer-Olkin) is at or above 0.5. Variables with a total correlation coefficient less than 0.3 are considered trash and will be removed from the scale. Eigenvalue stops (representing the variability explained by each factor) are greater than 1 and the cumulative\% Extraction Sums of Squared Loadings is greater than $50 \%$. Variables with a single correlation coefficient between variables and factors less than 0.5 will be excluded. To achieve discriminant validity, the difference between factor load factors must be greater than or equal to 0.3 (Henseler et al., 2009, 2015). The method of extracting "Principal Axis Factoring" with the "Promax" rotation is used in the factor analysis of independent components. The salient feature of EFA is that factors are drawn from statistical results, not from theory. The basic structure of the data determines the factor structure. Thus, EFA is conducted without knowing how many factors and each observing variable will belong to. Factors appearing are only named after the factor analysis. Composite Reliability (CR) is greater than 0.7. Test research hypotheses are accomplished by Bootstrap technique in Smart PLS software.

\section{Research results}

Results of assessing the reliability of the scales and testing of EFA on SPSS show that all scales meet the condition that Cronbach Alpha is greater than 0.7 and the total correlation coefficient is greater than 0.3. All scales are eligible for inclusion in the EFA discovery factor analysis. With KMO test significant at $1 \%(\mathrm{P}<0.000)$. After the rotation, we extracted 5 factors corresponding to 5 potential variables. Particularly, the Green supply chain management variable is a second-order factor variable, so the first order factor variables of this variable are gathered into one variable (Henseler et al., 2009, 2015).

\section{Table 1}

Construct Reliability and Validity

\begin{tabular}{lcccc}
\hline & $\begin{array}{c}\text { Cronbach's } \\
\text { Alpha }\end{array}$ & rho_A & $\begin{array}{c}\text { Composite } \\
\text { Reliability }\end{array}$ & $\begin{array}{c}\text { Average Variance } \\
\text { Extracted (AVE) }\end{array}$ \\
\hline Competitiveness & 0.838 & 0.842 & 0.839 & 0.635 \\
Corporate environment policy & 0.910 & 0.911 & 0.910 & 0.629 \\
Economic transport & 0.898 & 0.898 & 0.898 & 0.638 \\
Environmental performance & 0.920 & 0.920 & 0.920 & 0.697 \\
Financial performance & 0.947 & 0.949 & 0.948 & 0.645 \\
Green capability & 0.872 & 0.872 & 0.872 & 0.694 \\
Green supply chain management & 0.981 & 0.981 & 0.981 & 0.668 \\
Packaging waste & 0.911 & 0.911 & 0.911 & 0.672 \\
Product recycling & 0.928 & 0.928 & 0.928 & 0.682 \\
Reputation & 0.945 & 0.945 & 0.945 & 0.775 \\
\hline
\end{tabular}

From the results in Table 1, all AVE values are greater than 0.5 so the scales are qualified. Next, the combined Cronbach Alpha coefficient is greater than 0.8 , so the scales have very good reliability (Hair et al., 2011, 2013, 2014; Henseler et al., 2009, 2015). Next, the results of the evaluation of the distinction are as given in Table 2. The results in Table 2 show that the values inside the table are all smaller than the diagonal values, they show the potential variables to ensure a discriminant value and qualify for the next analysis. 
Table 2

Discriminant Validity

\begin{tabular}{|c|c|c|c|c|c|c|c|c|c|c|}
\hline & 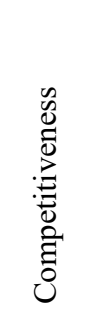 & 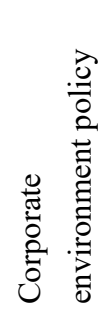 & 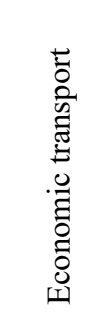 & 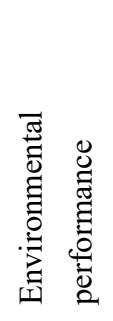 & 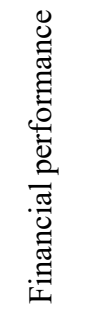 & 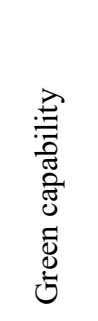 & 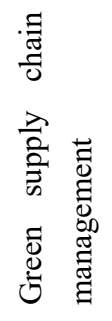 & 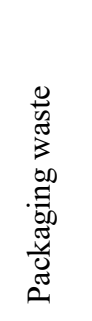 & 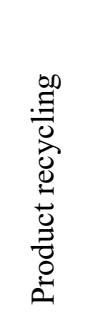 & 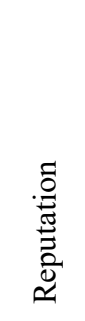 \\
\hline Competitiveness & 0.797 & & & & & & & & & \\
\hline Corporate environment policy & 0.197 & 0.793 & & & & & & & & \\
\hline Economic transport & 0.240 & 0.049 & 0.799 & & & & & & & \\
\hline Environmental performance & 0.222 & 0.474 & 0.470 & 0.835 & & & & & & \\
\hline Financial performance & 0.339 & 0.326 & 0.367 & 0.538 & 0.803 & & & & & \\
\hline Green capability & 0.221 & 0.037 & 0.022 & 0.430 & 0.315 & 0.833 & & & & \\
\hline Green supply chain management & 0.211 & 0.041 & 0.038 & 0.457 & 0.334 & 0.016 & 0.818 & & & \\
\hline Packaging waste & 0.185 & 0.020 & 0.009 & 0.450 & 0.330 & 0.067 & 0.012 & 0.820 & & \\
\hline Product recycling & 0.223 & 0.030 & 0.026 & 0.461 & 0.333 & 0.194 & 0.021 & 0.188 & 0.826 & \\
\hline Reputation & 0.359 & 0.172 & 0.193 & 0.237 & 0.381 & 0.169 & 0.181 & 0.164 & 0.204 & 0.880 \\
\hline
\end{tabular}

Table 3

The summary of Fit Summary

\begin{tabular}{lll}
\hline & Saturated Model & Estimated Model \\
\hline SRMR & 0.056 & 0.058 \\
d_ULS & 0.956 & 1.001 \\
d_G & 0.456 & 0.488 \\
Chi-Square & $1,688.796$ & $1,708.832$ \\
NFI & 0.883 & 0.889 \\
\hline
\end{tabular}

Table 4

The results of R-Square

\begin{tabular}{lll}
\hline & R Square & R Square Adjusted \\
\hline Competitiveness & 0.045 & 0.042 \\
Environmental performance & 0.209 & 0.207 \\
Financial performance & 0.380 & 0.375 \\
Green supply chain management & 1.040 & 1.041 \\
Reputation & 0.033 & 0.030 \\
\hline
\end{tabular}

\section{Table 5}

The results of F-Square

\begin{tabular}{|c|c|c|c|c|c|c|c|c|c|c|}
\hline & 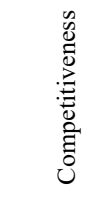 & 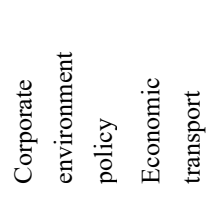 & 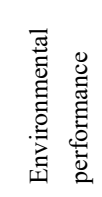 & 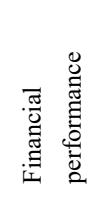 & 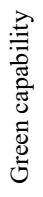 & 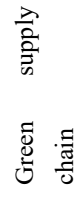 & 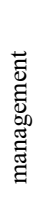 & 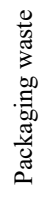 & 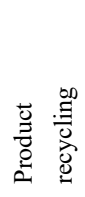 & 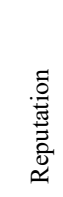 \\
\hline Competitiveness & & & & 0.152 & & & & & & \\
\hline Corporate environment policy & & & & & & 0.168 & & & & \\
\hline Economic transport & & & & & & 0.182 & & & & \\
\hline Environmental performance & & & & 0.303 & & & & & & \\
\hline \multicolumn{11}{|l|}{ Financial performance } \\
\hline Green capability & & & & & & 0.188 & & & & \\
\hline Green supply chain management & 0.163 & & 0.264 & & & & & & & 0.212 \\
\hline Packaging waste & & & & & & 0.191 & & & & \\
\hline Product recycling & & & & & & 0.198 & & & & \\
\hline Reputation & & & & 0.172 & & & & & & \\
\hline
\end{tabular}


The values of $f$ - square are satisfied, thus the underlying variables in the model have the ability to link to form meaningful models. Next, we evaluate the impact of the latent variables according to the research hypotheses.

\section{Table 4}

Path Coefficients

\begin{tabular}{|c|c|c|c|c|c|c|c|c|c|c|}
\hline & 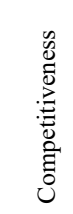 & 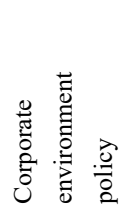 & 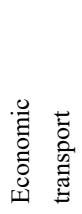 & 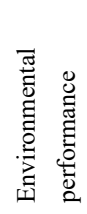 & 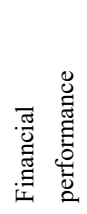 & 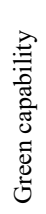 & 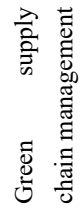 & 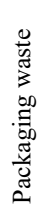 & 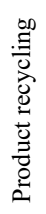 & 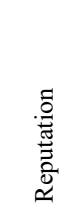 \\
\hline Competitiveness & & & & & 0.161 & & & & & \\
\hline Corporate environment policy & & & & & & & 0.180 & & & \\
\hline Economic transport & & & & & & & 0.151 & & & \\
\hline Environmental performance & & & & & 0.451 & & & & & \\
\hline \multicolumn{11}{|l|}{ Financial performance } \\
\hline Green capability & & & & & & & 0.085 & & & \\
\hline Green supply chain management & 0.211 & & & 0.457 & & & & & & 0.181 \\
\hline Packaging waste & & & & & & & 0.193 & & & \\
\hline Product recycling & & & & & & & 0.405 & & & \\
\hline Reputation & & & & & 0.216 & & & & & \\
\hline
\end{tabular}

\section{Table 5}

\section{Total Effects}

\begin{tabular}{|c|c|c|c|c|c|c|c|c|c|c|}
\hline & 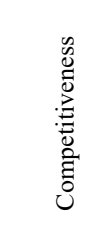 & 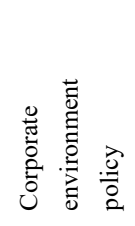 & 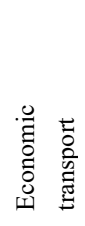 & 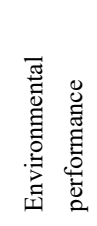 & 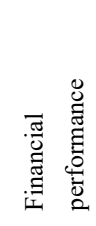 & 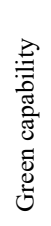 & 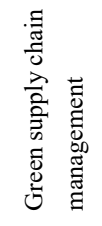 & 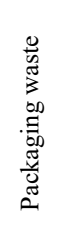 & 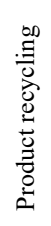 & 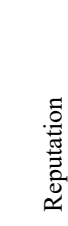 \\
\hline Competitiveness & & & & & 0.161 & & & & & \\
\hline Corporate environment policy & 0.038 & & & 0.082 & 0.050 & & 0.180 & & & 0.033 \\
\hline Economic transport & 0.032 & & & 0.069 & 0.042 & & 0.151 & & & 0.027 \\
\hline Environmental performance & & & & & 0.451 & & & & & \\
\hline \multicolumn{11}{|l|}{ Financial performance } \\
\hline Green capability & 0.018 & & & 0.039 & 0.024 & & 0.085 & & & 0.016 \\
\hline Green supply chain management & 0.211 & & & 0.457 & 0.280 & & & & & 0.181 \\
\hline Packaging waste & 0.041 & & & 0.088 & 0.054 & & 0.193 & & & 0.035 \\
\hline Product recycling & 0.086 & & & 0.185 & 0.113 & & 0.405 & & & 0.073 \\
\hline Reputation & & & & & 0.216 & & & & & \\
\hline
\end{tabular}

With the impact factors of the above factors, we perform Bootstrapping technique to test the research hypotheses, the test results are given in Fig. 2 as follows:

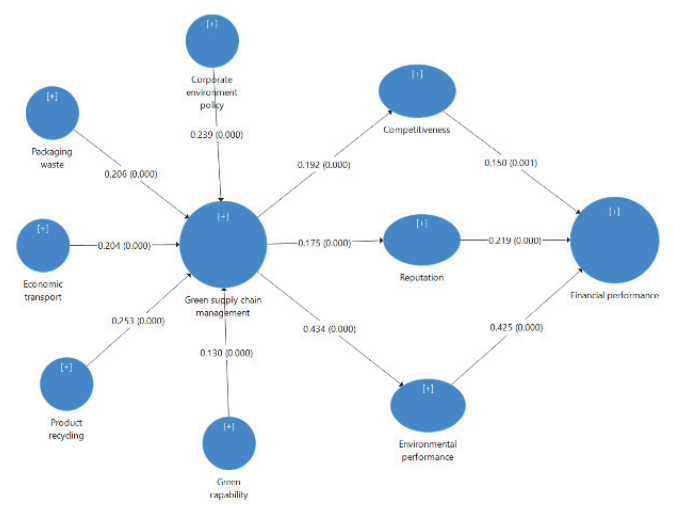

Fig. 2. Hypothesis test results 
From the test results in Fig. 2, it is shown that all first order factor variables are statistically significant constituting variables, the second order factor is Green supply chain management. With the indices of the first order factor Corporate environment policy variables respectively; packaging waste; Economic transport; Product recycling and Green capability are: $0.239 ; 0.206 ; 0.204 ; 0.253$ and 0.130 , respectively and all are at $1 \%$ significance level $\left(\mathrm{P}_{-}\right.$value $\left.=0.000\right)$. Hypotheses $\mathrm{H} 1, \mathrm{H} 2, \mathrm{H} 3, \mathrm{H} 4, \mathrm{H} 5$, H6 are accepted at the $1 \%$ significance level $\left(\mathrm{P}_{-}\right.$value $\left.<0.01\right)$. In particular, Green supply chain management has the strongest impact on Environment performance at the impact level of 0.434 at the $1 \%$ significance level $\left(\mathrm{P}_{-}\right.$value $\left.=0.000\right)$. It is quite understandable that when tourism businesses in Hanoi practice green supply chain management, all their activities from purchasing input products will be selected to be green. Using and providing services also focus on transportation, reducing emissions, using energy efficiently, policies on reuse of recycled products and environmental protection policies of the company. The first and most obvious outcome is the reduction of negative impacts on the environment and thus a strong positive impact on the environmental performance of the business. So the hypothesis of this relationship is supported. Next, environmental efficiency also has a very strong positive impact on the financial efficiency of tourism businesses in Hanoi. When the environmental efficiency is achieved, the waste treatment costs, discharge norms, administrative fines for discharges are reduced significantly, thereby saving costs for businesses, in addition to environmental efficiency. good schools, all stages of production activities or provide services are reduced costs so financial efficiency improved markedly. Therefore, the environmental effect has a very strong positive impact on the financial efficiency at the impact level of 0.425 with a $1 \%$ significance level $\left(\mathrm{P}_{\text {_value }}=0.000\right)$. Green supply chain management also has a statistically positive impact on Competitiveness and Reputation with impact levels of 0.192 and 0.175 with the same statistical significance of $1 \%(\mathrm{P}$ _value $=0.000)$. This shows the great role of strategic direction of green supply chain management, which will bring positive impacts for tourism businesses in particular and businesses in general. Implementing green supply chain management will enhance the company's competitive advantage, improve its image and reputation. Consumers, customers, and suppliers will know that the business is a responsible business ethic and thereby more loyal and committed to the business. It is an important premise to improve financial efficiency for businesses as well as sustainable development. In addition to the extremely strong impact of Environment performance on financial performance, Competitiveness and Corporate reputation also impact quite strongly on financial performance with 0.150 and 0.219 impact levels at $1 \%$ significance levels $\left(\mathrm{P}_{-}\right.$value $=0.001$ and $\mathrm{P}_{-}$value $\left.=0.000\right)$. When tourism businesses in particular and any other businesses in general have a good competitive advantage and good reputation and image, it will bring financial performance directly or indirectly with money. With a good brand, businesses can franchise their brand to gain financial benefits in cash or it can be a factor helping businesses attract talent and retain loyal customers, thereby reducing recruitment costs, training to improve productivity, reduce costs to find customers and improv their financial efficiency. Thus, the first 6 hypotheses are supported. Next, we test the remaining 2 hypotheses to test the mediating role of three intermediary variables in the research model. Fig. 3 shows the example of a simple mediator model, whereby $\mathrm{p} 3$ is the direct effect, $\mathrm{p} 1 \cdot \mathrm{p} 2$ is the indirect effect, and the direct effect $(\mathrm{p} 3)+$ the indirect effect $(\mathrm{p} 1 \cdot \mathrm{p} 2)=$ the total effect:

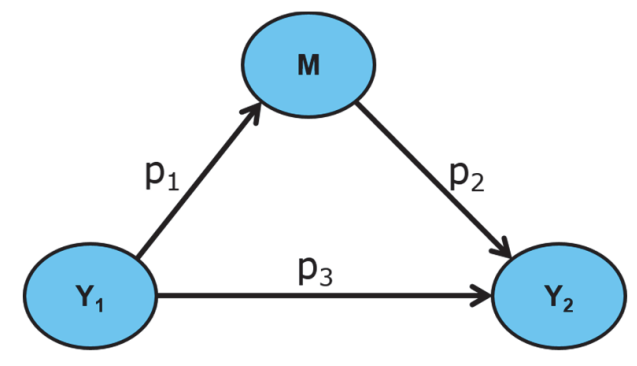

Fig. 3. Mediator 
To analyze a mediator model, Zhao et al. (2010) suggest a model, as shown in the following figure, which Hair et al. (2017) also propose to use for PLS-SEM:

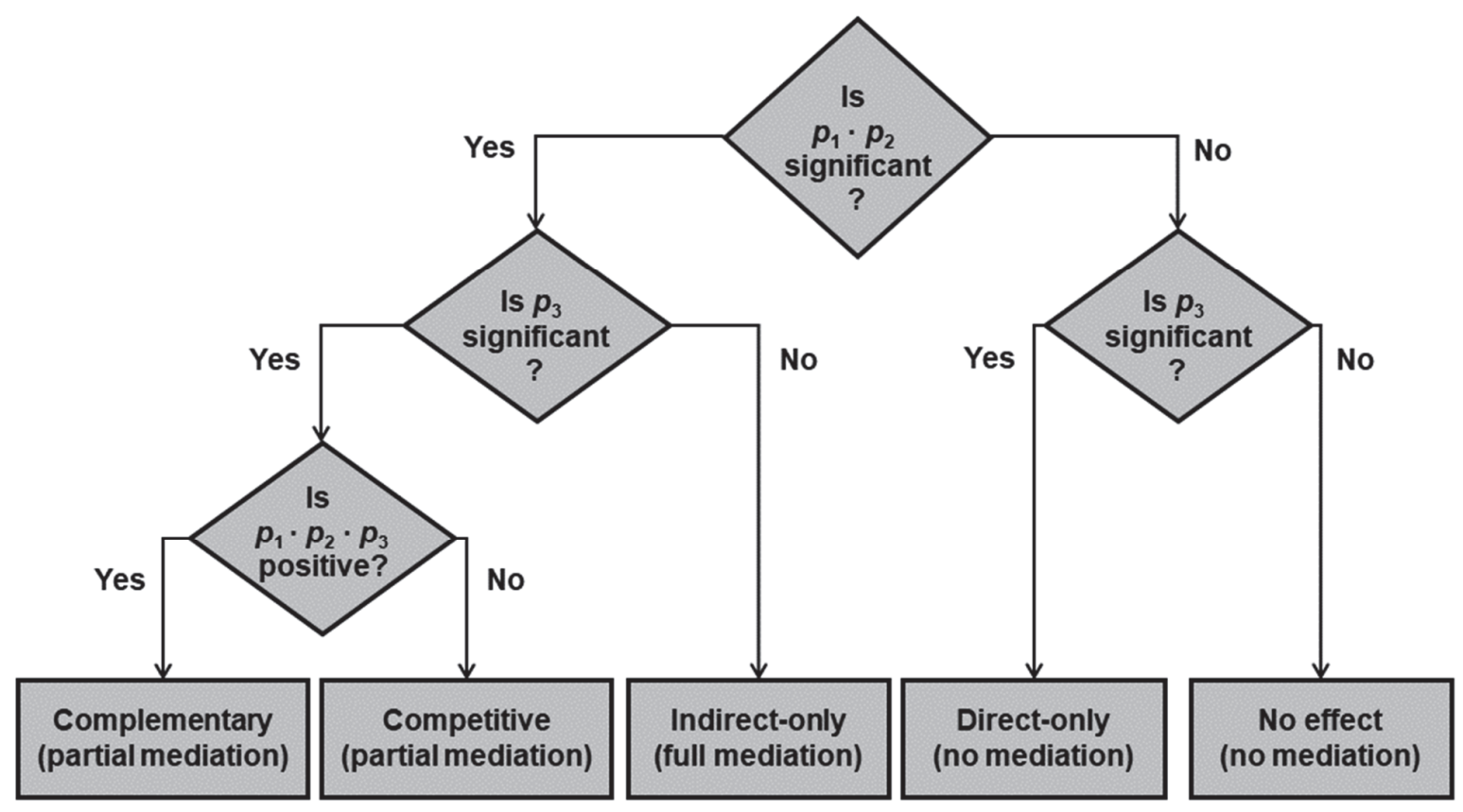

Fig. 4. Mediating role testing process

So step 1 is that the assumptions 1 through 6 are statistically significant, so the next determinations are eligible for implementation. We conducted the direct test of GSCM to Financial performance with the following results:

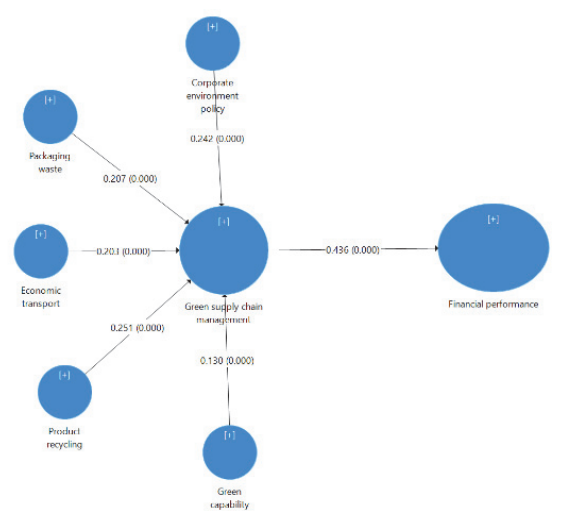

Fig. 5. Direct effect

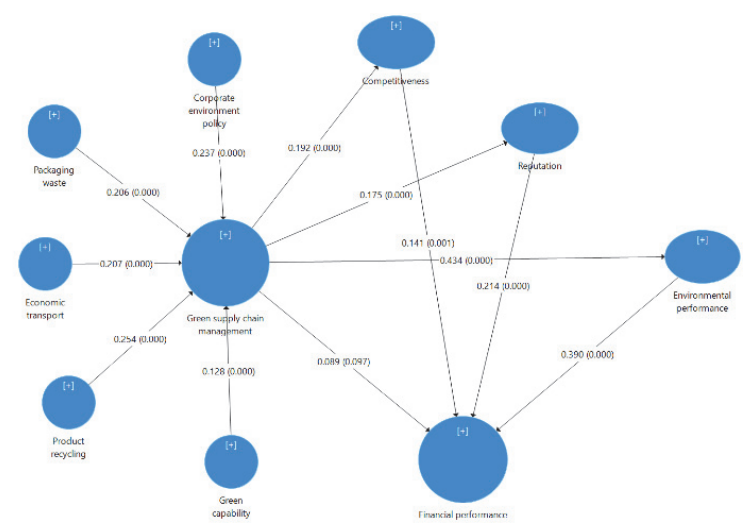

Fig. 6. Mediate role

The direct effect of Green Supply Chain Management on Financial performance is very strong at 0.436 with $1 \%$ significance level $\left(\mathrm{P}_{-}\right.$value $\left.=0.000\right)$. Thus, it satisfies the conditions to save the intermediate role of intermediate variables. Next, we conduct a mediate role test of mediate variables in the overall SEM model. The following results:

From the results in Fig. 6, it is shown that in this overall SEM model, the relationship between Green supply chain management and financial performance is no longer statistically significant. Therefore, according to Hair et al. (2017); Preacher (2015) Competitiveness; Reputation and Environment performance play a comprehensive intermediary role in the relationship between Green supply chain management and financial performance. The detailed results are as follows: 
Table 6

Specific Indirect Effects

\begin{tabular}{|c|c|c|c|c|c|}
\hline & 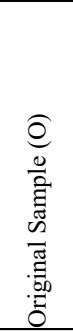 & 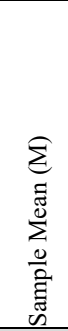 & 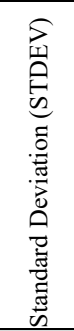 & 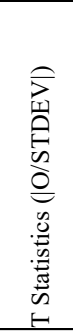 & $\frac{\mathscr{d}}{\Xi}$ \\
\hline Corporate environment policy $\rightarrow$ Green supply chain management $\rightarrow$ Competitiveness & 0.046 & 0.046 & 0.012 & 3.866 & 0 \\
\hline Economic transport $\rightarrow$ Green supply chain management $\rightarrow$ Competitiveness & 0.039 & 0.04 & 0.011 & 3.735 & 0 \\
\hline Green capability $\rightarrow$ Green supply chain management $\rightarrow$ Competitiveness & 0.025 & 0.025 & 0.007 & 3.707 & 0 \\
\hline Packaging waste $\rightarrow$ Green supply chain management $\rightarrow$ Competitiveness & 0.04 & 0.04 & 0.01 & 3.885 & 0 \\
\hline Product recycling $\rightarrow$ Green supply chain management $\rightarrow$ Competitiveness & 0.049 & 0.049 & 0.013 & 3.794 & 0 \\
\hline Corporate environment policy $\rightarrow$ Green supply chain management $\rightarrow$ Environmental performance & 0.104 & 0.104 & 0.011 & 9.663 & 0 \\
\hline Economic transport $\rightarrow$ Green supply chain management $\rightarrow$ Environmental performance & 0.089 & 0.089 & 0.009 & 9.958 & 0 \\
\hline Green capability $\rightarrow$ Green supply chain management $\rightarrow$ Environmental performance & 0.056 & 0.056 & 0.006 & 9.15 & 0 \\
\hline Packaging waste $\rightarrow$ Green supply chain management $\rightarrow$ Environmental performance & 0.089 & 0.09 & 0.009 & 9.531 & 0 \\
\hline Product recycling $\rightarrow$ Green supply chain management $\rightarrow$ Environmental performance & 0.11 & 0.11 & 0.011 & 9.993 & 0 \\
\hline $\begin{array}{l}\text { Corporate environment policy } \rightarrow \text { Green supply chain management } \rightarrow \text { Competitiveness } \rightarrow \text { Financial } \\
\text { performance }\end{array}$ & 0.007 & 0.007 & 0.003 & 2.393 & 0.017 \\
\hline Economic transport $\rightarrow$ Green supply chain management $\rightarrow$ Competitiveness $\rightarrow$ Financial performance & 0.006 & 0.006 & 0.002 & 2.362 & 0.018 \\
\hline Green capability $\rightarrow$ Green supply chain management $\rightarrow$ Competitiveness $\rightarrow$ Financial performance & 0.004 & 0.004 & 0.002 & 2.35 & 0.019 \\
\hline Packaging waste $\rightarrow$ Green supply chain management $\rightarrow$ Competitiveness $\rightarrow$ Financial performance & 0.006 & 0.006 & 0.002 & 2.412 & 0.016 \\
\hline Green supply chain management $\rightarrow$ Competitiveness $\rightarrow$ Financial performance & 0.029 & 0.029 & 0.012 & 2.383 & 0.017 \\
\hline Product recycling $\rightarrow$ Green supply chain management $\rightarrow$ Competitiveness $\rightarrow$ Financial performance & 0.007 & 0.007 & 0.003 & 2.369 & 0.018 \\
\hline $\begin{array}{l}\text { Corporate environment policy } \rightarrow \text { Green supply chain management } \rightarrow \text { Environmental performance } \rightarrow \\
\text { Financial performance }\end{array}$ & 0.044 & 0.045 & 0.007 & 6.523 & 0 \\
\hline $\begin{array}{l}\text { Economic transport } \rightarrow \text { Green supply chain management } \rightarrow \text { Environmental performance } \rightarrow \text { Financial } \\
\text { performance }\end{array}$ & 0.038 & 0.038 & 0.006 & 6.365 & 0 \\
\hline $\begin{array}{l}\text { Green capability } \rightarrow \text { Green supply chain management } \rightarrow \text { Environmental performance } \rightarrow \text { Financial } \\
\text { performance }\end{array}$ & 0.024 & 0.024 & 0.004 & 6.266 & 0 \\
\hline $\begin{array}{l}\text { Packaging waste } \rightarrow \text { Green supply chain management } \rightarrow \text { Environmental performance } \rightarrow \text { Financial } \\
\text { performance }\end{array}$ & 0.038 & 0.038 & 0.006 & 6.35 & 0 \\
\hline Green supply chain management $\rightarrow$ Environmental performance $\rightarrow$ Financial performance & 0.185 & 0.187 & 0.028 & 6.518 & 0 \\
\hline $\begin{array}{l}\text { Product recycling } \rightarrow \text { Green supply chain management } \rightarrow \text { Environmental performance } \rightarrow \text { Financial } \\
\text { performance }\end{array}$ & 0.047 & 0.047 & 0.007 & 6.515 & 0 \\
\hline Corporate environment policy $\rightarrow$ Green supply chain management $\rightarrow$ Reputation $\rightarrow$ Financial performance & 0.009 & 0.009 & 0.004 & 2.607 & 0.009 \\
\hline Economic transport $\rightarrow$ Green supply chain management $\rightarrow$ Reputation $\rightarrow$ Financial performance & 0.008 & 0.008 & 0.003 & 2.593 & 0.01 \\
\hline Green capability $\rightarrow$ Green supply chain management $\rightarrow$ Reputation $\rightarrow$ Financial performance & 0.005 & 0.005 & 0.002 & 2.645 & 0.008 \\
\hline Packaging waste $\rightarrow$ Green supply chain management $\rightarrow$ Reputation $\rightarrow$ Financial performance & 0.008 & 0.008 & 0.003 & 2.625 & 0.009 \\
\hline Green supply chain management $\rightarrow$ Reputation $\rightarrow$ Financial performance & 0.038 & 0.039 & 0.015 & 2.614 & 0.009 \\
\hline Product recycling $\rightarrow$ Green supply chain management $\rightarrow$ Reputation $\rightarrow$ Financial performance & 0.01 & 0.01 & 0.004 & 2.583 & 0.01 \\
\hline Corporate environment policy $\rightarrow$ Green supply chain management $\rightarrow$ Reputation & 0.042 & 0.043 & 0.012 & 3.572 & 0 \\
\hline Economic transport $\rightarrow$ Green supply chain management $\rightarrow$ Reputation & 0.036 & 0.036 & 0.01 & 3.536 & 0 \\
\hline Green capability $\rightarrow$ Green supply chain management $\rightarrow$ Reputation & 0.023 & 0.023 & 0.006 & 3.519 & 0 \\
\hline Packaging waste $\rightarrow$ Green supply chain management $\rightarrow$ Reputation & 0.036 & 0.036 & 0.01 & 3.615 & 0 \\
\hline Product recycling $\rightarrow$ Green supply chain management $\rightarrow$ Reputation & 0.044 & 0.045 & 0.013 & 3.525 & 0 \\
\hline
\end{tabular}

\section{Conclusion}

The results of the analysis have shown that the implementation of green supply chain management in tourism in particular and in the economy in general is very necessary. Implementing the green supply chain management will help businesses improve environmental management efficiency, enhance competitive advantage, image of business reputation and thereby improve financial efficiency for businesses. However, in order to implement green supply chain management, it is necessary to promote innovation, innovation, development and application of technology, from policy making and to practicing the principles of green business, job creation and green investment in tourism-related infrastructure, road transport, airports, parks and conservation areas, cities to reduce carbon emissions sustainably, along with the design of green building. 
Here we give some recommendations for some types of tourism business in Hanoi, Vietnam.

\section{For accommodation services}

On the accommodation side: Accommodation services will have to plan for more efficient use of energy. Many large hotels such as the Maldives, Lanzarote, Kingfisher Bay (Australia), Mauritius and many other places are using renewable energy sources. Some hotels use water saving systems, reusing wastewater for irrigation (gray water), using solar energy and wind energy. International hotel chains Marriott, Radisson SAS, TUI and Accor Hotels and Resorts regularly organize training programs on environmental issues such as waste management, treatment and recycling.

The hotel management practices both help reduce operating costs of the hotel, minimize the impact of the tourism industry on environmental pollution, build a good image of the hotel, and also show responsibility society of the business.

Regarding the management agencies: The management agencies also have many measures to manage and improve the environmental pollution situation of the tourism industry. For example, put in place a system of standards and permits (including eco-labeling), conduct a strict audit of activities that pollute the environment, and issue clear regulations for accommodation facilities. when polluting the environment. Regulations on responsibility to pollute the environment are also closely associated with the management of human resources.

In addition to the strict compliance with the law, some international hotel chains also set up an environmental self-certification system with a higher requirement than the government. For example, Marriot, Radisson, Hilton and Accord hotels signed recognition agreements with the Swiss travel system and the Spanish hotel operating system Iberosta awarded awards for tourism and the environment. In contrast, well-known travel companies in the world have also set up environmental standards and awarded awards for accommodation units such as Kuoni Switzerland, TUI, MyTravel Northern Europe, First Choice, Hotelplan.

\section{For shipping service}

Travel companies are unable to cut $\mathrm{CO}_{2}$ emissions by transportation, but travel companies can design itineraries and use transportation for tourists that produce less emissions. Many travel agencies also propose initiatives. Vasco Travel asks the driver to turn off the engine when the car stops at red lights or waiting for guests. Some travel agencies charge environmental costs into their prices (usually companies targeting high-income tourists) such as High and Wild, Greentours, The Expedition Company, Discovery Initiatives, Club Robinson - part of TUI, South American Experience Ltd, The Last Resort, Wildlife World, Crystal. However, some argue that the calculation of environmental costs in trip costs and the use of solutions to reduce environmental pollution do not have much impact on reducing pollution, but they also contribute to create Raise tourists' awareness of environmental issues.

\section{For moving ground service, entertainment}

Travel agencies also shift most of their products to ecotourism activities. The most typical example is the tour guide, the local tourism office is trained to guide tourists to comply with itinerary regulations to ensure minimizing environmental impact and maximizing economic benefits for Local tourism service provider. However, this measure is not very effective, because most local tourism workers are low-skilled workers, seasonal workers while local tourism companies do not want to spend money on training for employees. Many travel companies that provide high quality travel services take other actions. Rainbow Tours, Inntravel and Guerba recognize the importance of choosing a local travel service provider based on community and human resource activities, and design an environmental protection clause in the service agreement with a local travel agency. In addition, the ground travel service also finds that eco-tourism packages have a significant negative impact on wildlife. The travel agency also designed the program to ensure the needs of nature exploration, while protecting nature. 


\section{For restaurant service, food}

Food is considered a source of great profits for the local people to organize tourism. The main criteria for feed suppliers are quality, reliability and quantity of food provided accompanied by food service which is the supply chain and distribution network between small suppliers and hotels. Many travel companies organize a journey to discover tourist destinations with local food, and are accompanied by lessons on the scarcity of specialties such as seafood, animals, etc.

\section{For destination travel service}

In the tourism service supply chain, destination travel services provide infrastructure and services. Travel destination services have the different functions: (i) to connect tourist sites and tourism activities to exploit economic benefits from tourism activities; (ii) to contribute to the introduction of locally grown and produced products instead of importing products to tourists; (iii) to connect investment activities and supporting capital for local tourism businesses to establish or expand businesses; (iv) to assist local labor in changing jobs to tourism (Macedonia). Thus, the green tourism chain is an indispensable requirement in the present life, requiring changes in the operational strategy of the tourism company from training workers, selecting partners, designing products in Chain. Governments of countries, including Vietnam, also cannot stand out, under pressure of change from consumers. It is important that we strengthen the propaganda of changing awareness on green tourism and putting pressure on building a green tourism supply chain. The Government needs to develop technical standards to ensure that the green tourism supply chain is operational; encourage tourism agencies to also design green tourism programs and responsible tourism. Travel companies and tourism companies have the responsibility to comply with and participate in the green tourism supply chain.

\section{References}

Bagur-Femenias, L., Llach, J., \& del Mar Alonso-Almeida, M. (2013). Is the adoption of environmental practices a strategical decision for small service companies? Management Decision, 51(1), 41-62.

Chan, E.S.W., \& Wong, S.C.K. (2006). Motivations for ISO 14001 in the hotel industry. Tourism Management, 27(3), 481-92.

Cepeda, G., Nitzl, C., \& Roldán, J. L. (2017). Mediation Analyses in Partial Least Squares Structural Equation Modeling: Guidelines and Empirical Examples., in Partial Least Squares Path Modeling: Basic Concepts, Methodological Issues and Applications, H. Latan and R. Noonan (eds.), Springer: Cham, pp. 173-195.

Chiu, J., \& Hsieh, C. (2016). The impact of restaurants' green supply chain practices on firm performance. Sustainability, 8(1), 42.

Dodds, R., \& Joppe, M. (2001). Promoting urban green tourism: The development of the other map of Toronto. Journal of Vacation Marketing, 7(3), 261-267.

Gimenez, C., \& Sierra, V. (2013). Sustainable supply chains: Governance mechanisms to greening suppliers. Journal of Business Ethics, 116(1), 189-203.

Golicic, S. L., \& Smith, C. D. (2013). A meta-analysis which investigates the relationship between environmental supply chain management and firm performance. Journal of Supply Chain Management, 49(2), 78-95.

Hair, J.F., Ringle, C.M., \& Sarstedt, M. (2011). PLS-SEM: in deed a silver bullet. Journal of Marketing Theory and Practice, 19(2), 139-151.

Hair, J.F., Hult, G.T.M., Ringle, C., \& Sarstedt, M. (2013). A Primer on Partial Least Squares Structural Equation Modeling (PLS-SEM), Sage Publications Ltd, London.

Hair, J.F., Henseler, J., Dijkstra, T., Sarstedt, M., Ringle, C., Diamantopoulos, A., Straub, D., Ketchen, D., GTM, H., \& Calantone, R. (2014). Common beliefs and reality about partial least squares: comments on Rönkkö and Evermann. Organizational Research Methods, 17(2), 182-209.

Hair, J. F., Hult, G. T. M., Ringle, C. M., \& Sarstedt, M. (2017). A Primer on Partial Least Squares Structural Equation Modeling (PLS-SEM), 2nd Ed., Sage: Thousand Oaks. 
Henseler, J., Ringle, C.M. and Sarstedt, M. (2015). A new criterion for assessing discriminant validity in variance-based structural equation modeling, Journal of the Academy of Marketing Science, 43(1), 115-135.

Henseler, J., Ringle, C.M. and Sinkovics, R.R. (2009). The use of partial least squares path modeling in international marketing, in Sinkovics, R.R. and Ghauri, P.N. (Eds), New Challenges to International Marketing, Emerald Group Publishing Limited.

Le, T., Nguyen, T., Phan, T., Tran, M., Phung, X., Tran, T., \& Giao, K. (2019). Impact of corporate social responsibility on supply chain management and financial performance in Vietnamese garment and textile firms. Uncertain Supply Chain Management, 7(4), 679-690.

Nitzl, C., Roldán, J. L., \& Cepeda Carrión, G. (2016). Mediation analysis in partial least squares path modeling: Helping researchers discuss more sophisticated models. Industrial Management \& Data Systems, 119(9), 1849-1864.

Preacher, K. (2015). Advances in mediation analysis: A survey and synthesis of new developments. Annual Review of Psychology, 66, 1-28.

Phan, T. T. H, Doan, X. T., \& Nguyen, T. T. T. (2020). The impact of supply chain practices on performance through supply chain integration in textile and garment industry of Vietnam. Uncertain Supply Chain Management, 8(1), 175-186.

Pintassilgo, P. (2016). Green tourism. In: Jafari J., Xiao H. (eds) Encyclopedia of Tourism. Springer, Cham

Porter, M. E., \& Kramer, M. R. (2006). Strategy \& society: The link between competitive advantage and corporate social responsibility. Harvard Business Review, 84(12), 78-92.

Paulraj, A. (2011). Understanding the relationships between internal resources and capabilities, sustainable supply management and organizational sustainability. Journal of Supply Chain Management, 47(1), 19-39.

Rao, P., \& Holt, D. (2005). Do green supply chains lead to competitiveness and economic performance? International Journal of Operations \& Production Management, 25(9), 898-916.

Rodriguez-Anto'n, J.M., Alonso-Almeida, M.M., Celemı'n, M., \& Rubio, L. (2012). Use of different sustainability management systems in the hospitality industry. The case of Spanish hotels. Journal of Cleaner Production, 22(1), 76-84.

Zeng, S.X., Meng, X.H., Yin, H.T., Tam, C.M., \& Sun, L. (2010). Impact of cleaner production on business performance, Journal of Cleaner Production, 18(10), 975-83.

Zhao, X., Lynch, J. G., \& Chen, Q. (2010). Reconsidering Baron and Kenny: Myths and Truths About Mediation Analysis. Journal of Consumer Research, 37(2), 197-206.

Zhu, Q., \& Sarkis, J. (2004). Relationships between operational practices and performance among early adopters of green supply chain management practices in Chinese manufacturing enterprises. Journal of Operations Management, 22, 265-289.

Zhu, Q., Sarkis, J., \& Lai, K. H. (2012). Examining the effects of green supply chain management practices and their mediations on performance improvements. International Journal of Production Research, 50(5), 1377-1394.

Zhu, Q., Sarkis, J., \& Geng, Y. (2005). Green supply chain management in China: Pressures, programs and performance. International Journal of Operations \& Production Management, 25(5), 449-468.

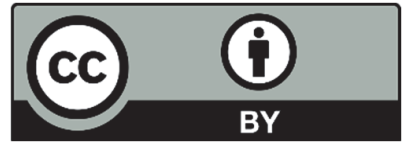

(C) 2020 by the authors; licensee Growing Science, Canada. This is an open access article distributed under the terms and conditions of the Creative Commons Attribution (CC-BY) license (http://creativecommons.org/licenses/by/4.0/). 